\title{
New Information on Yom Tob Atias (alias Alvaro Vargas), Co-publisher of the Ferrara Bible
}

Aron di Leone LEONI

Fifty years ago the scholars were unanimously convinced that the Spanish Bible of Ferrara (1553) was printed in two editions: one for Jews, and one for Christians. These differed only in the dedications and in a few details in the text. The so called "Jewish edition" was presented to doña Gracia Naci while the "Christian" one was dedicated to Duke Hercules the second ${ }^{1}$.

After examining almost all the available copies of the Bible, in 1955 Stanley Rypins proved that there was one only edition, with two different types of volume ${ }^{2}$. The variations were introduced in the course of the run ${ }^{3}$. From a technical point of view this was certainly true.

Uriel Macías has recently called attention to a distinctive feature of major importance: the insertion, in the "Jewish" version, of two additional folios with the "Tabla de las haphtaroth de todo el año» ${ }^{4}$.

\footnotetext{
${ }^{1}$ Cf. J. B. DE Rossi, De Typographia Hebraeo Ferrariensi commentarius historicus quo ferrarienses judaeorum editiones hebraicae hispanicae lusitanae recensentur et illustrantur (Parma 1780) pp. 69-73; and Cecil RoTH, "The Marrano press at Ferrara", The Modern Language Review 38 (1943) pp. 307-312.

${ }^{2}$ S. Rypins, "The Ferrara Bible at Press", The Library (A Quarterly Review of Bibliography) Series 5, 10 (1955) pp. 244-269.

${ }^{3}$ H. P. Salomon, Deux études portugaises / Two Portuguese Studies (Braga 1991) pp. 50-57.

${ }^{4}$ Uriel Macías KAPÓN, "La Biblia de Ferrara en bibliotecas y bibliografías españolas", in Introducción a la Biblia de Ferrara, Actas del Simposio Interna-
} 
According to tradition, the publisher(s) and the printer of the Bible signed the Prologo to Doña Gracia Naci with their Jewish names (Yom Tob Atias and Abraham Usque) and used their Christian (baptismal) names (Jerónimo de Vargas and Duarte Pinel) in the dedication to Duke Hercules.

In 1989 Yosef Hayim Yerushalmi expressed for the first time "a measure of skepticism" as to the identification of Abraham Usque with Duarte Pinel and of Jerónimo de Vargas with Yom Tob Atias ${ }^{5}$.

Renata Segre has recently discovered a document concerning Abraham Usque "vulgo cognominatus Odoardo [= Duarte] Pinellus lusitanus" ${ }^{6}$. She did not give any similar evidence on the (supposed) identification of Jerónimo Vargas with Yom Tob Atias. However, she did not question it and stated that Jerónimo used his Portuguese name "alternately with that of Yom Tob» ${ }^{7}$. But it was not so.

I was lucky enough to find a 1556 notary deed by which Don Jacob Abravanel ${ }^{8}$ acknowledged that he was holding two printing presses and other tools which Jerónimo Vargas had rented from G. M. Niccolini (in 1552). Don Jacob stated that «torcularia, et bona penes se deposuisse Joantu' Athias Lusitanum, procuratorem et legitimum administratorem dicti Hieronimi

cional sobre la Biblia de Ferrara ... de 1991, ed. I. M. HASSÁN (Madrid 1992) pp. 473-502: pp. 477 and 481 and table on p. 485; cf. Iacob M. HASSÁN, "Dos introducciones de la Biblia de Ferrara", in Introducción a la Biblia de Ferrara pp. 13-66: pp. 35 and 43 . Towards the end of the 18th century, G. F. DE BURE mentioned the Tabla de las haphtaroth in his Bibliographie instructive ou traité de la connaissance des livres rares et singuliers: Volume de Théologie (Paris 1763) p. 98. Although G. B. De Rossi examined several copies of the Spanish Bible, he had no chance to see this table and could not describe it. This was probably the reason why C. Roth, after De Rossi, and many Italian authors, following C. Roth, did not pay attention to this non incidental difference. Cf., for instance, R. SEGRE, "Contribución documental a la historia de la imprenta Usque y de su edición de la Biblia", in Introducción a la Biblia de Ferrara pp. 205-226.

${ }^{5}$ Y. H. Yerushalmi, A Jewish Classic in the Portuguese Language, introduction to Samuel Usque's Consolaçam as Tribulaçoes de Israel (reimp. Lisboa 1989) pp. 86-87.

"Segre «Contribución" p. 218.

7 SEgRe "Contribución" pp. 220-221. In the notarial documents the name is given also as Joanto, Joampto and Joamtu'.

${ }^{8}$ On Jacob Abravanel, one of Don Samuel's sons, see A. di Leone Leoni, "Nuove Notizie sugli Abravanel", Zakhor 1 (1997) pp. 153-206. 
Vargas». Even if he was not involved in the matter ${ }^{9}$, Jacob Abravanel was prepared to pay Niccolini the rent eventually due "quandocumque ... computum fecerit cum dicto Hieronimo de Vargas vel cum dicto Joamtu' eius patre et legitimo administratore» ${ }^{10}$. Yom Tob Atias was therefore Jerónimo's legal representative, trustee and father. The wording of the deed is extremely clear and does not leave any doubt as to the relationship between Jerónimo Vargas and his father Yom Tob Atias.

We learn the baptismal name of Yom Tob Atias (alias Álvaro Vargas) from a deed of 1557: at this time Álvaro was acting as guardian of his orphaned minor nephews, the children of the late Duarte Vargas: he entrusted three merchants living in Portugal with the task of recovering Duarte's assets in that country ${ }^{11}$. In doing so, Álvaro ${ }^{12}$ acted also in his capacity of father and "legitimo administratore ... Hieronimi Vargas" ${ }^{13}$. It may hence be inferred that Álvaro was the same person as Yom Tob.

I did not succeed in finding the Jewish name of Jerónimo. The place and date of his birth are unknown. We do not even know when and whence he arrived in Ferrara.

The first member of the Vargas family mentioned in a Ferrarese notarial deed was Odoardo de Vargas, Lusitanian. On December the $7^{\text {th }} 1551$ Guiomar Laines, the widow and testamentary executor of Antonio Rodrigues, acknowledged that her late husband was holding 725 "scudi de marcho" on behalf of Duarte. The sum had been deposited in Lyon in the Bank of Nicola and Carlo Antenori, under the name of Rodrigues. Guiomar allowed Duarte to claim his money, with the due lucro, directly from the two Florentine merchants ${ }^{14}$. The document

\footnotetext{
${ }^{9}$ On the dispute between Jerónimo de Vargas and Giovan Maria Niccolini, see SEgRE "Contribución" pp. 209-210 and 213.

${ }^{10}$ Archivio di Stato di Ferrara (= ASFe), notary Nicola Caprilli, Matr. 504, Pacco 2, November $2^{\text {nd }} 1556$.

${ }^{11}$ ASFe, notary Giacomo Conti, Matr 584, Pacco 7, May $12^{\text {th }} 1557$. Cf. SEGRE "Contribución" p. 221 note 41.

${ }_{12}$ Italian Jews considered the name Alvaro as equivalent of ha-Leví. Cf. SEgRE "Contribución" p. 215 note 24.

${ }^{13}$ Hieronimo and Duarte had evidently been business partners.

${ }^{14}$ ASFe, notary Giacomo Conti, Pacco 5S (sub data).
} 
does not state whether Duarte lived in Ferrara at the time. He had already settled in this city on July the $6^{\text {th }} 1552$ when he bought 11 woollen pieces from the Camera Ducale ${ }^{15}$ together with two merchants of his nation. Three months later he bought 12 more pieces ${ }^{16}$.

Jerónimo de Vargas described himself as a Spaniard in the colophon of the Bible ("Christian" variant) ${ }^{17}$. The specification was not casual: it was meant to stress the cultural and affective linkage with his (or his family's) land of origin ${ }^{18}$. As far as I know he was called "hispano" only on another occasion ${ }^{19}$.

However, he called himself a Portuguese in his dealings with the ducal government. In an undated (1551) statement presented to the Duke ${ }^{20}$, Didacus (Diego) Pyrrhus (at that time engaged in the publishing enterprise) and Hyeroniomus Vargas, both Lusitanian, mentioned the privilege allowing them to print books, especially in Spanish ${ }^{21}$. The two partners requested judicial intervention against two Italian printers hired for the purpose: unfortunately, they had proved to be lazy and inefficient.

In the notarial documents drawn up in Ferrara, Jerónimo presented himself as a Portuguese (or Lusitanian) merchant without stating his religious affiliation. For instance, on August

${ }^{15}$ Archivio di Stato di Modena (= ASMo), Arch. per Materie, Arti e Mestieri, Arte della Lana, B.32: Notta delli panni venduti a diversi mercanti al tempo quali panni si sono fabbricati novamente a nome della Ducal Camera jn Castello Nuovo (sub data).

${ }^{16}$ ASMo, Notta delli panni venduti ..., October $17^{\text {th }} 1552$. On the subject of the textile factory, cf. A. di Leone LeONI, "La Diplomazia Estense e l'Immigrazione dei Cristiani Nuovi a Ferrara al Tempo di Ercole II", Nuova Rivista Storica 78 (1994) pp. 293-325: p. 321; and Claudio Ancona, Ercole II d'Este ed i mercanti portoghesi (unpublished master degree, State University of Milan 1995).

${ }_{17}$ Biblia de Ferrara, f. 3D10r/401a, reproduced by HASSÁN "Dos introducciones" p. 44; cf. his analysis in p. 45.

${ }_{18}$ Cf. HASSÁn "Dos introducciones" p. 46.

19 Title page of the Processus domini Hieronimi Vargas Hispani cum Magistro Leonardo de Brixia impressore, ASMo, Arch. per Materie, Arti e Mestieri, B.36. Jerónimo was however called Portuguese in the papers of this file.

${ }^{20}$ Processus domini Hieronimi Vargas ..., ASMo, Arch. per Materie ..., B. 36, undated statement with ducal rescript of November $11^{\text {th }} 1551$. Cf. SEgRE "Contribución" p. 209.

${ }^{21}$ Cf. the legend "Con priuillegio del yllustrissimo Señor Duque de Ferrara" on the lower part of the title page of the Biblia de Ferrara, f. *1r/[I]a, reproduced by HASSÁN "Dos introducciones" pp. 34 (and 37). 
the $29^{\text {th }} 1553$ the "Honorandus vir Dominus Hieronimus de Vargas lusitanus" conferred power of attorney upon the Florentine merchant Gino Capponi and entrusted him to collect all his [unspecified] credits from the Antenori's banking and trading company ${ }^{22}$.

Jerónimo eventually stated himself to be Jewish in a notarial deed drawn up in Pesaro on December the $9^{\text {th }}$ 1557: "Dominus Hieronymus de Varghas hebreus Portughensis in presentiarum moram trahens in civitate Pisauri». He entrusted a Ferrara lawyer and his father Levyas ${ }^{23}$ Atias to bring a (new) suit against the printer G. M. Niccolini ${ }^{24}$.

Jerónimo returned to Ferrara in 1557 and once again described himself as a Portuguese merchant: "Dominus Hieronimus de Vargas mercator lusitanus Ferrariae morans" conferred power of attorney upon the Spanish merchant Odoardo Furtado in order to collect his credits from Nicola and Carlo Antenori in Florence ${ }^{25}$.

On March the $4^{\text {th }} 1559$ (the heirs of) Duarte Vargas paid the Ducal Chamber 99 ducats in settlement for an old supply of woollen clothes ${ }^{26}$. Thereafter nothing more is heard of the Atias-Vargas Family in Ferrara.

\footnotetext{
${ }^{22}$ ASFe, notary Giacomo Conti, Pacco 5S (sub data).

${ }^{23}$ The appellative Levyas (Leyvas) fitted Yom Tob well: he had signed the Livro de Oracyones de todo el año (Ferrara 1552) and the colophon of the Bible ("Jewish" variant) as Yom Tob hijo de Levi Atias. Cf. H. P. Salomon, "Hispanic Liturgy among Western Sephardim", The American Sephardi 2 (1968) pp. 49-59; Yerushalmi A Jewish Classic p. 86; and Hassán "Dos introducciones" pp. 44-45.

${ }^{24}$ Archivio di Stato di Pesaro, notary Francesco Fattori, vol. 9, ff. 84r-85r.

${ }^{25}$ ASFe, notary Giacomo Conti, Pacco 8, May $28^{\text {th }} 1557$.

${ }^{26}$ ASMo, Camera Ducale, Libri Camerali Diversi: Libro Zornale dell'Arte della Lana, 1555-1561, f. 21v.
} 


\section{RESUMEN}

Según la tradición, la Biblia de Ferrara (1553) salió a la luz gracias a la labor artística de Abraham Usque (alias Duarte Pinel) y al apoyo finaciero de Yom Tob Atias (alias Jerónimo Vargas). Gracias a una escritura notarial de 1556 sabemos que Yom Tob y Jerónimo no son la misma persona: Yom Tob Atias (alias Álvaro Vargas) era el padre de Jerónimo. Éste último se definía como español en el colofón de la Biblia, pero en sus relaciones comerciales se declaraba mercader portugués o lusitano. Aunque no haya duda de que volvió al judaísmo, no sabemos cuándo tuvo lugar. Todavía se desconoce su nombre judío.

\section{SUMMARY}

According to tradition, the Ferrara Bible (1553) appeared in print thanks to Abraham Usque's technical and artistic mastery and Yom Tob Atias's financial backing. Usque's alias was Duarte Pinel; Atias's was Jerónimo Vargas. In light of a 1556 notarial document, it is now known that Yom Tob and Jerónimo were not one and the same person. A different Yom Tob Atias (alias Álvaro Vargas) was Jerónimo's father. In the colophon to the Bible, Jerónimo wrote that he was Spanish. Yet in his commercial relations he is always documented as a Portuguese merchant. Though it is certain that he formally converted to Judaism, his date of conversion is unknown. Equally unknown is his Jewish adopted name. 